\title{
Hubungan periodontitis dengan penyakit jantung koroner pada pasien di RSUP Prof. Dr. R. D. Kandou Manado
}

\author{
1 Jolanda P. Ticoalu \\ ${ }^{2}$ Billy J. Kepel \\ ${ }^{3}$ Christy N. Mintjelungan
}

\author{
${ }^{1}$ Kandidat Skripsi Program Studi Pendidikan Dokter Gigi Fakultas Kedokteran \\ ${ }^{2}$ Bagian Kimia Fakultas Kedokteran \\ ${ }^{2}$ Program Studi Pendidikan Dokter Gigi Fakultas Kedokteran \\ Universitas Sam Ratulangi Manado \\ Email: ticoalujolanda@ymail.com
}

\begin{abstract}
Periodontitis is one of the factors causing systemic disease. It is often associated with increasing signs of inflammation and it is also an indicator of the risk factors of coronary heart disease (CHD). Infection of periodontal structures can accelerate the form of atherosclerosis that causes coronary heart disease due to systemic inflammation through the release of endotoxins, proteins, or acute phase reactors. This was a case control analytical study with a cross sectional design conducted at Prof. Dr. R. D. Kandou Hospital Manado from August to September 2016. There were 40 respondents (20 CHD patients and 20 nonCHD patients) obtained by using total sampling method. Periodontal disease indexes of the samples were evaluated by using periodontal disease index of Ramfjord 1959. The Chi-square test showed a $\mathrm{p}$ value of 0.01 . Conclusion: There was a significant relationship between periodontitis and coronary heart disease in patients at Prof. Dr. R. D. Kandou Hospital Manado.
\end{abstract}

Keywords: periodontitis, Coronary Heart Disease (CHD)

\begin{abstract}
Abstrak: Periodontitis merupakan salah satu faktor penyebab penyakit sistemik. Pada periodontitis sering didapatkan peningkatan tanda-tanda inflamasi yang juga merupakan salah satu indikator dari faktor risiko penyakit jantung koroner (PJK). Infeksi struktur periodontal dapat mempercepat pembentukan aterosklerosis yang menjadi penyebab PJK dengan cara menimbulkan inflamasi sistemik melalui pelepasan endotoksin, protein, atau reaktor fase akut. Jenis penelitian ialah analitik menggunakan case control dengan desain potong lintang. Penelitian dilakukan di RSUP Prof. Dr. R. D. Kandou Manado pada bulan Agustus sampai September 2016. Terdapat 40 responden (20 pasien PJK dan 20 pasien non PJK) diperoleh dengan menggunakan metode total sampling. Pada penelitian ini dilakukan pengukuran indeks penyakit periodontal menggunakan pengukuran PDI Ramfjord 1959. Analisis data menggunakan uji Chi-square. Hasil analisis bivariat menggunakan uji Chi-square menunjukkan nilai $p=0,01 \quad(0,01<0,05)$ yang menyatakan bahwa terdapat hubungan antara periodontitis dengan PJK pada pasien di RSUP Prof. Dr. R. D. Kandou Manado. Simpulan: Terdapat hubungan bermakna antara periodontitis dengan penyakit jantung koroner pada pasien di RSUP Prof. Dr. R. D. Kandou Manado.
\end{abstract}

Kata kunci: periodontitis, penyakit jantung koroner (PJK)

Negara Indonesia merupakan salah satu negara yang sedang berkembang di dunia. Umumnya di negara yang sedang berkembang, pengetahuan masyarakat mengenai kesehatan gigi dan rongga mulut masih kurang. Masyarakat cenderung lebih 
mengutamakan kesehatan tubuh secara umum yang dianggap lebih penting dan membutuhkan penanganan cepat. ${ }^{1}$ Terdapat berbagai gangguan kesehatan yang dapat disebabkan oleh infeksi di dalam rongga mulut. Teori focal infection menyata-kan bahwa mikroorganisme dalam rongga mulut merupakan sumber infeksi terhadap bagian tubuh yang lain. ${ }^{2}$

Penyakit periodontal merupakan salah satu penyakit gigi dan mulut yang banyak dijumpai di masyarakat dunia khususnya di Indonesia. Penyakit periodontal yang banyak dijumpai yaitu gingivitis dan periodontitis. $^{3} \quad$ Prevalensi penyakit periodontal cukup tinggi di masyarakat dengan angka kejadian penyakit pada semua kelompok usia di Indonesia mencapai $96,58 \%{ }^{1}$

Periodontitis merupakan penyakit yang menyerang jaringan periodontal disebabkan oleh infeksi mikroorganisme di dalam rongga mulut. Hal ini menyebabkan terjadinya inflamasi kronis pada jaringan penyangga gigi yang terdiri dari gingiva, tulang alveolar, ligamen periodontal, dan sementum. ${ }^{4}$

Periodontitis merupakan faktor resiko beberapa penyakit sistemik. ${ }^{5}$ Pada kondisi periodontitis sering didapatkan adanya peningkatan tanda-tanda inflamasi, yang juga merupakan indikator dari faktor risiko penyakit jantung koroner (PJK). Bakteri yang berasal dari poket periodontal dapat masuk ke dalam aliran darah selama terjadi aktivitas rongga mulut misalnya saat mengunyah dan menggosok gigi. ${ }^{6}$ Infeksi dari sturuktur periodontal dapat mempercepat pembentukan aterosklerosis yang menjadi penyebab PJK dengan cara menimbulkan inflamasi sistemik melalui pelepasan endotoksin, protein, atau reaktor fase-akut. $^{6}$

PJK ialah kondisi yang terjadi akibat penumpukan plak di arteri jantung sehingga mengakibatkan pasokan darah ke jantung terganggu. PJK merupakan penyebab utama kematian di seluruh dunia. Sekitar 3,8 juta laki-laki dan 3,4 juta perempuan meninggal akibat penyakit tersebut setiap tahunnya. WHO mencatat lebih dari 7 juta orang meninggal di seluruh dunia pada tahun 2002 akibat PJK. Angka ini diperkirakan meningkat hingga 11 juta di tahun $2020 .^{7}$

Dalam beberapa penelitian secara garis besar terdapat hubungan antara penyakit periodontal dengan PJK. Kesehatan rongga mulut yang buruk menjadi salah satu faktor resiko penyakit kardiovaskular. ${ }^{6}$ Suatu penelitian prospektif yang dilakukan oleh Wu et al. menunjukkan adanya peningkatan keparahan mulai dari gingivitis, periodontitis, sampai kondisi edentulosis yang berhubungan dengan peningkatan risiko PJK, dan periodontitis merupakan faktor risiko terjadinya PJK seperti halnya hiperlipidemia, kadar fibrinogen, dan Creaktif protein ${ }^{4}$

Penelitian ini bertujuan untuk mengetahui hubungan penyakit periodontitis dengan PJK pada pasien yang dirawat di RSUP Prof. Dr. R. D. Kandou Manado.

\section{BAHAN DAN METODE PENELITIAN}

Penelitian ini dilakukan di RSUP Prof. Dr. R. D. Kandou Manado pada bulan Agustus-September 2016. responden diperoleh dengan metode total sampling. Pada penelitian ini dilakukan pengukuran indeks penyakit periodontal menggunakan pengukuran PDI Ramfjord 1959. Analisis data hasil penelitian diolah dengan menggunakan Uji Chi-square.

\section{HASIL PENELITIAN}

Tabel 1 memperlihatkan bahwa berdasar-kan jenis kelamin baik responden PJK maupun non PJK laki-laki lebih dominan $(75 \%)$ dibandingkan perempuan (15\%). Jumlah yang sama pada responden non PJK merupakan kesesuaian persamaan dengan kelompok PJK

Tabel 1. Distribusi responden PJK dan Non PJK berdasarkan jenis kelamin

\begin{tabular}{ccccc}
\hline \multirow{2}{*}{ Jenis kelamin } & \multicolumn{2}{c}{ PJK } & \multicolumn{2}{c}{ Non PJK } \\
\cline { 2 - 5 } & $\mathrm{n}$ & $\%$ & $\mathrm{n}$ & $\%$ \\
\hline $\mathrm{L}$ & 15 & 75 & 15 & 75 \\
$\mathrm{P}$ & 5 & 15 & 5 & 15 \\
Total & 20 & 100 & 20 & 100 \\
\hline
\end{tabular}


Tabel 2 menunjukkan distribusi responden berdasarkan usia. Responden PJK terbanyak pada kelompok usia 51-60 tahun dengan jumlah 10 orang $(50 \%)$ dan yang paling sedikit pada kelompok usia 7180 tahun sebanyak 1 orang (5\%). Pada responden non PJK responden terbanyak pada kelompok usia 51-60 tahun dengan jumlah 8 orang $(40 \%)$ dan yang paling sedikit yaitu kelompok usia 71-80 tahun sebanyak 1 orang $(5 \%)$.

Tabel 2. Distribusi responden PJK dan non PJK berdasarkan usia

\begin{tabular}{ccccc}
\hline Usia & \multicolumn{2}{c}{ PJK } & \multicolumn{2}{c}{ Non PJK } \\
\cline { 2 - 5 } (Tahun) & $\mathrm{n}$ & $\%$ & $\mathrm{n}$ & $\%$ \\
\hline $41-50$ & 4 & 20 & 7 & 35 \\
$51-60$ & 10 & 50 & 8 & 40 \\
$61-70$ & 5 & 25 & 4 & 20 \\
$71-80$ & 1 & 5 & 1 & 5 \\
Total & 20 & 100 & 20 & 100 \\
\hline
\end{tabular}

Tabel 3 menunjukkan responden tidak periodontitis lebih banyak dengan jumlah 24 orang $(60 \%)$ sedangkan responden dengan periodontitis berjumlah lebih sedikit yaitu 16 orang $(40 \%)$.

Tabel 3. Distribusi status periodontitis pada responden

\begin{tabular}{ccc}
\hline Periodontitis & n & $\%$ \\
\hline Ya & 16 & 40 \\
Tidak & 24 & 60 \\
Total & 40 & 100 \\
\hline
\end{tabular}

Tabel 4 menunjukkan jumlah responden dengan PJK dan non PJK masing-masing sebanyak 20 orang $(50 \%)$

Tabel 4. Distribusi status PJK pada responden

\begin{tabular}{ccc}
\hline PJK & n & \% \\
\hline Ya & 20 & 50 \\
Tidak & 20 & 50 \\
Total & 40 & 100 \\
\hline
\end{tabular}

Tabel 5 menunjukkan terdapat 12 orang (60\%) dengan kasus periodontitis pada responden dengan PJK dan sebanyak 8 orang $(40 \%)$ dengan tidak periodontitis pada responden dengan PJK.

Tabel 5. Distribusi status periodontitis pada responden dengan PJK

\begin{tabular}{ccc}
\hline Periodontitis & n & \% \\
\hline Ya & 12 & 60 \\
Tidak & 8 & 40 \\
\hline Total & 20 & 100 \\
\hline
\end{tabular}

Hasil penelitian menunjukkan terdapat 12 orang $(30 \%)$ dengan kasus periodontitis pada kelompok pasien PJK dan 4 orang (10\%) dengan kasus periodontitis pada kelompok pasien non PJK.

Berdasarkan hasil uji analisis uji statistik chi-square ditemukan nilai $\mathrm{p}=$ 0,01 yang menunjukkan adanya hubungan bermakna antara periodontitis dengan PJK (Tabel 6).

Tabel 6. Hubungan periodontitis dengan PJK pada Pasien di RSUP Prof. Dr. R. D. Kandou Manado

\begin{tabular}{|c|c|c|c|c|c|c|c|}
\hline \multirow{3}{*}{ Periodontitis } & \multicolumn{4}{|c|}{ Status PJK } & \multirow{2}{*}{\multicolumn{2}{|c|}{ Total }} & \multirow{3}{*}{$\mathbf{p}$} \\
\hline & \multicolumn{2}{|c|}{ PJK } & \multicolumn{2}{|c|}{ Non PJK } & & & \\
\hline & $\mathrm{n}$ & $\%$ & $\mathrm{n}$ & $\%$ & $\mathrm{n}$ & $\%$ & \\
\hline Ya & 12 & 30 & 4 & 10 & 16 & 40 & 0,01 \\
\hline Tidak & 8 & 20 & 16 & 40 & 24 & 60 & \\
\hline Total & 20 & & 20 & & 40 & 100 & \\
\hline
\end{tabular}

\section{BAHASAN}

Penyakit jantung koroner (PJK) merupa-kan suatu penyakit yang terjadi akibat penyumbatan pembuluh arteri koronaria yang terdapat pada jantung.
Penyumbatan ini dapat mengurangi atau memutuskan pasokan darah untuk menenuhi kebutuhan oksigen dan nutrisi bagi jantung itu sendiri. Hal ini dapat menyebabkan keadaan patologik yang 
reversibel seperti infark miokard akut, sampai keadaan patologis yang irreversibel seperti nekrosis otot jantung. Inflamasi dinding pembuluh darah dan penimbunan lemak merupakan faktor yang paling banyak menyebabkan sumbatan yang mungkin dapat dikaitkan dengan penyakit periodontal.

Adanya infeksi jaringan periodontal dapat menyebabkan suatu episode singkat terjadinya bakteriemia. Keadaan ini menyebabkan periodontitis berhubungan secara langsung dengan kejadian PJK sebab bakteri rongga mulut mempunyai pengaruh langsung yaitu sebagai mediator terjadinya penyakit vaskular. ${ }^{8}$

Pada penelitian ini (Tabel 2) terjadinya penyakit jantung koroner dominan pada laki-laki (75\%) dibandingkan pada perempuan $(15 \%)$. Hal ini dikarenakan risiko aterosklerosis koroner lebih besar pada laki-laki dibandingkan pada perempuan. Perempuan relatif lebih kebal terhadap penyakit ini tetapi setelah usia menopause menjadi sama rentannya seperti pada laki-laki. Efek perlindungan estrogen dianggap menjelaskan adanya imunitas wanita pada usia sebelum menopause yaitu melindungi tubuh dari kerusakan. ${ }^{9}$ Hal ini sesuai dengan hasil penelitian Namawi et al. (2006) bahwa jenis kelamin dominan sindrom koroner akut ialah laki-laki. ${ }^{10}$

Dari hasil penelitian (Tabel 3) didapatkan terjadinya penyakit jantung koroner (PJK) dominan pada kelompok usia 51-60 tahun berjumlah 10 orang $(50 \%)$. Hasil penelitian ini sesuai dengan penelitian Dtrong dan McGill bahwa aterosklerosis berawal pada masa anakanak dan perlahan-lahan menjadi lebih banyak pada usia dewasa yang selanjutnya akan mendorong terjadinya penyumbatan arteri. Risiko PJK terjadi pada usia 40-60 tahun dan pada wanita menopaus. ${ }^{11} \mathrm{Hal}$ ini juga sejalan dengn teori Davidson yaitu bertambahnya umur akan meningkatkan risiko kejadian penyakit jantung koroner. Hasil penelitian Djohan (2004) juga mendapatkan adanya hubungan antara usia dengan kejadian PJK. Kasus PJK akan meningkat dengan bertambahnya usia. ${ }^{12}$
Hasil di atas menjelaskan bahwa kejadian PJK bukanlah suatu kejadian yang terjadi secara tiba-tiba, tetapi berkelangsungan lama. Selain itu juga semakin tua bagian organ tubuh manusia, maka semakin menurun pula kemampuannya untuk berfungsi, dan jika dikombinasikan dengan faktor-faktor genetik serta faktor lain, maka hal ini potensial meningkatkan terjadinya PJK. ${ }^{11}$

Periodontitis merupakan salah satu faktor yang dapat memicu risiko lebih besar pada individu untuk terjadinya PJK. ${ }^{13}$ Hasil ini serupa dengan penelitian yang dilakukan oleh Hatta ${ }^{6}$ yang mendapatkan bahwa penyakit periodontal memiliki hubungan bermakna dengan kejadian penyakit aterosklerosis. Hasil penelitian Beck et al. ${ }^{8}$ menyatakan bahwa terdapat hubungan antara penyakit periodontal dengan penyakit jantung koroner, akan tetapi banyak variabel lain yang menjadi perancunya.

Dalam penelitian ini ditemukan kasus periodontitis pada pasien non PJK (kelompok kontrol). Peneliti berasumsi bahwa kebanyakan kelompok tersebut merupakan pasien rawat inap bedah dengan kurangnya kemampuan pasien untuk beraktivitas pada keadaan tidak sehat dapat menurunkan niat seseorang untuk membersihkan diri dalam hal ini menggosok gigi. Selama satu bulan penelitian, peneliti menemukan adanya pasien yang sama dan masih menerima perawatan di instalasi rawat inap bedah, dan dari hasil penelitian tidak semua pasien memiliki kondisi rongga mulut yang baik/sehat sehingga menimbulkan masalah. Keadaan pasien yang tidak sehat dapat memperburuk kondisi rongga mulut pasien. Hasil yang sama juga diperoleh berdasarkan penelitian oleh Neto et al. yang dilakukan di RS Londrina Brazil menemukan bahwa status kesehatan mulut pasien rawat inap di rumah sakit buruk dan sebagian besar membutuhkan perawatan kesehatan mulut, terlihat dari odds ratio oral hygiene terhadap lesi oral $(\mathrm{OR}=3,11)$ dan oral hygien terhadap penyakit periodontal $(\mathrm{OR}=2,10)$. Oral hygiene dan 
akumulasi plak gigi sebagai penyebab utama terjadinya inflamasi gingiva serta termasuk faktor risiko memburuknya status kesehatan sistemik seseorang. ${ }^{15}$

\section{SIMPULAN}

Berdasarkan hasil penelitian yang dilakukan di RSUP Prof. Dr. R. D. Kandou Manado dapat disimpulkan bahwa terdapat hubungan bermakna antara periodontitis dengan penyakit jantung koroner pada pasien di RSUP Prof. Dr. R. D. Kandou Manado.

\section{SARAN}

1. Perlu dilakukan penelitian lebih lanjut dengan jumlah sampel yang lebih banyak dengan waktu yang lebih panjang untuk mengetahui tentang hubungan periodontitis dengan penyakit jantung koroner.

2. Perlu adanya kerjasama pelayanan kesehatan gigi dan mulut dengan poli jantung dan instalasi rawat inap bedah terutama di RSUP Prof. Dr. R. D. Kandou Manado dalam meminimalisasi terjadinya penyakit periodontal.

3. Diharapkan tenaga medis khusunya dalam bidang kesehatan gigi dan mulut agar lebih memperhatikan dalam upaya promotif dan preventif kedokteran gigi.

\section{DAFTAR PUSTAKA}

1. Lestari AB. Status penyakit periodontal masyarakat Kabupaten Tana Toraja ditinjau dari pengetahuan, sikap dan perilaku [Skripsi]. Makassar: Universitas Hassanudin; 2013.

2. Sariningsih E. Gigi busuk dan Periodontal sebagai Fokus Infeksi. Jakarta: Elex Media Komputindo, 2014; p. 25.

3. Riset Kesehatan Dasar (RISKESDAS). Badan Penelitian dan Pengembangan Kesehatan. Jakarta. Departemen Kesehatan Republik Indonesia, 2007

4. Samad R. Periodontitis dan Risiko Penyakit Jantung Koroner. Makassar: IPB Press, 2012; p. 54, 64.
5. Samad R. Implikasi periodontitis terhadap aterosklerosis: Hubungannya dengan profil Lipid dan kadar serum hs-CRP. IJD. 2006;Edisi khusus KPP/KG XIV:234

6. Hatta M. Penyakit periodontal dan hjubungannya dengan aterosklerosis [Skripsi]. Makassar: Universitas Hassanudin; 2011.

7. Afriyanti R, Pangemanan J, Palar S. Hubungan antara perilaku merokok dengan kejadian penyakit jantung koroner. eCl. 2015;3:99.

8. Beck JD, Slade G, Offenbacher S. Oral disease, cardiovascular and systemic inflammation. Periodontology. 2000; 23(1):110-20.

9. Brown CT. Penyakit Aterosklerotik Koroner. Jakarta: EGC, 2006.

10. Nawawie RA, Fitriani, Rusli B, Hardjoeno. Nilai troponin T (CTNT) penderita sindrom koroner akut (SKA). Indonesian Journal of Clinical Pathology and Medical Laboratory. 2006;3:123-6.

11. Nababan D. Hubungan faktor risiko dan karakteristik penderita dengan kejadian penyakit jantung koroner di RSU Dr. Pirngadi Medan [Tesis]. Medan: Sekolah Pascasarjana Universitas Sumatera Utara; 2008.

12. Supriyono M. Faktor-faktor risiko yang berpengaruh terhadap kejadian penyakit jantung koroner pada kelompok usia $\leq 45$ tahun [Tesis]. Semarang: Program Pasca SarjanaMagister Epidemiologi Universitas Diponegoro; 2008.

13. Sembiring IC. Periodontitis suatu faktor risiko terjadinya penyakit jantung koroner [Skripsi]. Medan: FKG Universitas Sumatera Utara; 2003.

14. Nugroho P. Penyakit periodontitis sebagai penyebab penyakit jantung koroner di RSUP Dr. Kariadi Semarang [Skripsi]. Semarang: Fakultas Kedokteran Universitas Diponegoro; 2011.

15. Patient care standars; Nursing process, diagnosis, and outcome Vol 3 . Jakarta: EGC, 1998. 